Portland State University

PDXScholar

$1-1-2011$

\title{
The Work of Promising and the Creation of Meaning
}

Evan Conrad Buswell

Portland State University

Follow this and additional works at: https://pdxscholar.library.pdx.edu/open_access_etds Let us know how access to this document benefits you.

\section{Recommended Citation}

Buswell, Evan Conrad, "The Work of Promising and the Creation of Meaning" (2011). Dissertations and Theses. Paper 166.

https://doi.org/10.15760/etd.166

This Thesis is brought to you for free and open access. It has been accepted for inclusion in Dissertations and Theses by an authorized administrator of PDXScholar. Please contact us if we can make this document more accessible: pdxscholar@pdx.edu. 
The Work of Promising and the Creation of Meaning

$$
\text { by }
$$

Evan Conrad Buswell

A thesis submitted in partial fulfillment

of the requirements for the degree of

\author{
Master of Arts \\ in \\ English
}

Thesis Committee:

Michael J. Clark, Chair

Marcia Klotz

Leerom Medovoi

Portland State University

2011 


\begin{abstract}
This thesis is an exploration into the mechanism of Marxist materialism. It is an attempt, in the face of materialism, to regain a grasp on our intellectual lives. The promise, I will argue, is a nexus between the material and ideal realms; it largely determines the configurations of our thoughts along three poles: privacy/recognition, sovereignty/subjection, and individual/society. In this thesis, I will explore the history of the promise during the sixteenth-century development of the negotiable instrument-a form of the promise that could be bought and sold. This development, I will argue, led to a general transformation of language during the sixteenth and seventeenth centuries such that the concept of the referent largely replaced the concept of the signifier. In the realm of mathematics, this transformation led to the creation of the symbolic variable; elsewhere, it led to the creation of what Mary Poovey has called the modern fact.
\end{abstract}




\section{Acknowledgments}

This has been a long process, and I would like to thank everyone who has made it possible: Marcia Klotz, for invaluable feedback and hours of inspiring conversations, Lee Medovoi, for his insightful critique, Michael Clark, for giving me license with confidence, Tom Luckett, for giving me some excellent research leads, Amy Greenstadt, for sound practical advice on managing a project like this, and Hayley Steele, for unwaveringly believing in me. There are more, of course; when a project consumes you, it has a way of pulling in all your interactions. So lastly, thank you to everyone with whom my life has intersected during this expedition—-for putting up with my non-sequiturs, and for all our conversations, which have probably been somehow incorporated into this project. 


\section{Contents}

Abstract .........................

Acknowledgments ........................... ii

List of Tables . . . . . . . . . . . . . . . . . . . iv

List of Figures . . . . . . . . . . . . . . . . . . . . . v

1 The Promise . . . . . . . . . . . . . . . . . . . . 1

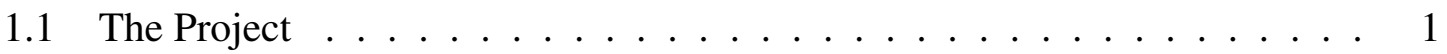

1.2 Apart from the Promise . . . . . . . . . . . . . . . 2

1.3 Abiding the Promise . . . . . . . . . . . . . . 4

1.4 The World of Promises . . . . . . . . . . . . . . . . 6

1.5 The Question of the Promise . . . . . . . . . . . . . . . 10

1.6 Other Theories: Nietzsche . . . . . . . . . . . . . . . . 13

1.7 Other Theories: Speech-Act Theory . . . . . . . . . . . . . . . 15

1.8 A Note on Historical Investigation and Method . . . . . . . . . . . . 17

2 The Formation of the Modern Promise in the West . . . . . . . . . . . . . . . 21

2.1 Historical Overview . . . . . . . . . . . . . . . . 21

2.2 Before Negotiability . . . . . . . . . . . . . . . . 23

2.3 The Transition to Negotiability . . . . . . . . . . . . . . . . 28

2.4 Further Developments . . . . . . . . . . . . . . . . . . . 32

3 Signification and Algebraic Language . . . . . . . . . . . . . . . . . . . . . . . . . . . . . . . . . . . . .

3.1 Fixed Meaning, Fluid Meaning . . . . . . . . . . . . . . . . . 36

3.2 Other Theories: Double-Entry Bookkeeping and the Modern Fact . . . . . . 38

3.3 Before the Variable . . . . . . . . . . . . . . . . . . 43

3.4 The Formation of the Variable . . . . . . . . . . . . . . . . . . . . . . . . . . . . . 45

3.5 Mode of Signification . . . . . . . . . . . . . . . . . . . . . . . . 49

3.6 Epistemic Justice . . . . . . . . . . . . . . . . . . 51

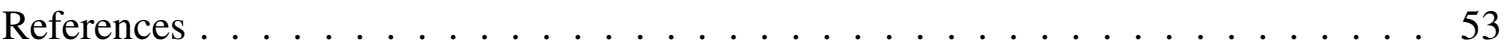


List of Tables iv

List of Tables

3.1 Pacioli's Notation for an Unknown and its Powers . . . . . . . . . . . . . . 44 
List of Figures

2.1 The Parties in a Transaction via Bill of Exchange . . . . . . . . . . . 24 


\section{The Promise}

\subsection{The Project}

This project provides one possible answer to a question posed by Marxist theory. As Marx tells us, the ideas of a given society arise from their material context. But this formula, and even more so the base-superstructure distinction that permeates later Marxist theory, provides us with more questions than answers. For those of us embedded in a life full of thoughts and feelings through which we navigate our world, it is deeply unsatisfactory to be unable to claim them. It is impossible to simply let go of our thoughts and live only the bare life of an object. And if Marx is right, then we are confronted by one giant question mark: how does the material context give rise to ideas? If we could understand this, we could understand how to rebuild and change that environment of thought which is so precious to us.

Of that giant question mark, I address only a small part. Loosely focused around various configurations of our ideas of truth and freedom, I will argue that the promise is an important nexus between the ideal and material. As through history we have adopted different practices of promising, these practices have suggested certain truths to us and altered the limits of what is publicly thinkable.

In Western Europe, the practice of promising has slowly brought us from direct, personal bonds to a vast network of credit relationships. The hinge of this movement, I will argue, is the development of negotiable paper, a textual form of the promise that is sufficiently solid and abstract that it can be transferred again and again yet still bind the 
promiser. With the negotiable promise, our word first becomes something that can be directly bought and sold. The pressure that the practice of negotiability puts on our ideal world has partially determined what it means for us to be subjects, the character of our scientific use of language, and the image of our unachieved freedom.

To frame and introduce my thoughts on the promise, I'll begin with three stories.

\subsection{Apart from the Promise}

First, a story I heard from an acquaintance. His grandfather and grandmother had been married for over a quarter-century—he didn't say whether they were happy or not, so I assume it was like most marriages: conflict and love, boredom and fulfillment. Then his grandmother passed away and his grandfather was left alone. After a few years, his grandfather fell for another woman, and these two stayed together for the remainder of his grandfather's life. But when they would come over to the grandchildren's house for dinner-even after twenty years, even when the grandchildren were old enough to know better-when the time came to leave, the grandfather would say: I'll take her home, and then I'll go home.

This would usually be called keeping up appearances, the words would be marked as meaningless protocol, and then the whole incident would be passed over. But let's consider the grandfather's two relationships.

The first relationship began as a boy and girl who got married. Also, possibly, simply keeping up appearances. But maybe, as he took his wedding vows, the boy meant 
every word. Maybe he wanted to bind himself, to wrap up his will with the fate of another, and express it the only way he could, with a ritual sentence: I do.

And then, if the grandfather had so bound his will up into this relationship, what would happen when the grandmother died? The piece of his will that extended over a quarter century would certainly return to him. But he would find it foreign, already given to another, inadequate for its reexpression towards anyone else. And when he moved on, might it not be with a different will, one more suited for another purpose than for marriage? Unable to promise, unable to exercise his will towards another, the grandfather hid behind a second ritual sentence: I'll take her home. And he coupled with another in the shadows, and let his words slip away from him, and let himself slip away from the public world of those words.

The first sentence, I do, spoken before witnesses, transforms the will into an object of the world. But by the time the second sentence is spoken, the last thing the grandfather wants is for his will to be an object of the world. His will, now, has become private, and all the words and witnesses, all the public things, should contradict it. Those words he speaks hide nothing, for everything is already known; but they create privacy for the very reason that when they appear, they appear as an untruth. What they communicate is their untruth, not their truth, the distance between public and private life, not their closeness, the distinction between appearance and truth, not their identity.

In some ways, this private life is full of freedom. Privacy cannot be judged if it cannot be publicized. But there is privation in privacy. One is free, but to what end? What is freedom if it isolates? What powers could we possibly obtain that would make up for 
the powers we lose: the power to be understood, to be incorporated into the world, to create something which lives on, without us, in another?

\subsection{Abiding the Promise}

The second story is about a promise that was held too long. A close friend of mine acceded too quickly to a promise of forever. He and his partner were speedily engaged, but the two plodded on for years in the space between the inception of the promise and the ritual of the marriage. As time passed, his desire for this relationship faded away. Having no children and no shared possessions, the only thing keeping them together was their promises to one another. It would be a simple thing to end for many, but this friend of mine was stubborn and wouldn't break his word. Unable to turn against his own promise, instead he fell silent and drifted off into inactivity, trying to wait out what he couldn't turn against. Needless to say, whatever the girl could see in her silent companion quickly disappeared, and she left.

My friend began intoxicated by his own will. And he conceived of the promise as a means to extend that will even towards the future. So he pointed his finger towards the future and spoke. But as time passed, that finger of power became a talisman of powerlessness. It would appear from the past, mummified and estranged from him, pointing the way with words that possessed his body, constraining his life such that he could not form it as he wanted.

As he began to realize this, the silence appeared, which was later to take hold of 
him stronger than the promise itself did. For he had been betrayed by his own will, facing him from the past; and after this betrayal, how could he trust it? One of two things was possible: either his will would be fickle, in which case it was meaningless, or it would be strong, and overshadow whatever choice he might want in the future. Better, so he thought, to not speak at all, to preserve the potential against the actual, to conserve his precious will, to hoard it, not allowing a penny be spent unless it was sure to be regained as specie. There are two sides to every promise. From the vantage point of the present, looking out towards the unknown future, our promises are magnificent specimens of willpower, able even to determine the future. More than that, they are the only thing that can add duration to our decisions and create a continuity and holism to our selves; they are emblems of the sovereignty of our souls. But once we have reached that future, all of our debts and promises arise as specters of the past that would possess the living; they become emblems of the subjection of the body. When promises turn against us, they wound us, and we are left living on in a world after the promise, where all promises are ghosts and all we can do is avoid possession. Navigating between the two sides of a promise, we try to create our souls and dispel our specters. Every promise is a negotiation between these two poles for which there can be no final arbitration. 


\subsection{The World of Promises}

Dubai paints itself as a city of gold pulled out of the desert. So they flock there from India, trying to get education for their children ${ }^{1}$ they flock there from the Philippines, looking for hope ${ }^{2}$ they flock there from Canada, searching for a high-roller lifestyle. ${ }^{3}$ And they get there, and they take out loans, because they have to pay a year's rent in advance, ${ }^{4}$ because their daughters need dowries, ${ }^{5}$ because they need to pay off the loan sharks that financed their trip, ${ }^{6}$ because they are too ashamed to disappoint friends and family back home, ${ }^{7}$ because the credit in Dubai flows like water. ${ }^{8}$ And then 2008 comes around, and real estate markets have collapsed worldwide, and there's a global

1. Vinita Bharadwaj, "Sending It All Back Home," The National, 12 September 2009, reprinted by Pravasi Bandhu, accessed 21 February 2011, http://pravasibandhu.blogspot.com/2009/09/sending-it-all-back-home.html.

2. Ola Galal, "Dubai's Expatriate Workers Feel Pinch of Debt Crisis," Monsters and Critics, 12 December 2009, accessed 30 October 2010,

http://www. monstersandcritics.com/news/business/features/article_1518701.php/Dubai-sexpatriate-workers-feel-pinch-of-debt-crisis-Feature.

3. Johann Hari, "The Dark Side of Dubai," The Independent, 7 April 2009, accessed 30 October 2010, http://www. independent.co.uk/opinion/commentators/johann-hari/the-dark-side-ofdubai-1664368.html.

4. Syed Ali, Dubai: Gilded Cage (New Haven: Yale University Press, 2010), 44.

5. Vinita Bharadwaj, "Sending It All Back Home."

6. Ibid.

7. Ibid.

8. Syed Ali, Dubai: Gilded Cage, 44. 
credit crunch, and their jobs are cut. ${ }^{9}$ Jobless, with their work visas canceled unless they can find another sponsor, some flee the country immediately. Some are not so decisive, and the banks freeze their accounts and cash the blank checks that function as security for the loans. The checks bounce, the authorities are notified, and many end up in jail. ${ }^{10}$

Then there's the personal fallout. Some commit suicide in shame, dashing across highways hoping that blood money, at least, will reach their relatives. ${ }^{11}$ In other cases, apologies are taped to the windshields of BMWs abandoned in airport parking lots, the keys in the ignition. ${ }^{12}$ An Indian philanthropist and radio show host sets up a charitable organization and flies around India, Dubai, and the rest of the Middle East giving seminars on how non-resident Indians should stop smoking and save their cigarette money, abandon the practice of demanding dowries, and put aside twenty percent of their paycheck as savings; and the audience cheers as the redeemed souls cut up their credit cards in a radio repentance. $^{13}$

9. "Dubai Faces Gradual Exodus of Expatriate Workers," Tehran Times, 7 January 2010, accessed 30 October 2010, http: / /www.tehrantimes.com/index_View. asp? code=211675.

10. See the article and the comments on Jeremy Lawrence, "Debt in Dubai," Time Out Dubai, 9 February 2009, accessed 30 October 2010,

http://www.timeoutdubai.com/knowledge/features/6433-debt-in-dubai.

11. Sunita Menon, "Desperate Laborers Seek Death on Roads," gulfnews.com, 29 March 2006, accessed 30 October 2010, http://gulfnews. com/news/gulf/uae/traffic-transport/desperatelabourers-seek-death-on-roads-1.230710.

12. Sonia Verma, "Driven Down by Debt, Dubai Expats Give New Meaning to Long-Stay Car Park,” The Times, 5 February 2009, accessed 30 October 2010, http://business.timesonline.co.uk/tol/business/markets/the_gulf/article5663618.ece.

13. Pravasi Bandhu Welfare Trust, “Our Mission,” Paravasi Bandhu Welfare Trust, accessed 21 February 2011, http://www.pravasibandhu.com/about/. Also, Vinita Bharadwaj, "A Kind Ear for Unsung Heroes," The National, 27 December 2008, accessed 21 February 2011, http://www.thenational.ae/lifestyle/personal-finance/a-kind-ear-for-unsung-heroes. 
In Dubai, there are no central credit-reporting agencies, and all the credit transactions, instead of depending on a system of massive surveillance, depend on the word of the borrower. ${ }^{14}$ Blank checks are demanded by banks as security for a personal loan. Car payments will be made by a thick handful of post-dated checks, each of which is cashed when it comes due. ${ }^{15}$ Bouncing a check is breaking your word, and the offenders are put in prison. As of 2007, forty percent of the inhabitants of Dubai's prisons were there for loan default. ${ }^{16}$ And as odd as it is, a lot of the international reaction sides against those who broke their word, as they had, after all, promised more than they could provide, and written checks which they could not cover. ${ }^{17}$

Clearly most of those who broke their word, if not all, were victims of forces beyond their own personal control. The collapse of the sub-prime housing market in the United States, among other things, sparked a chain reaction across the globe. As various banks began to understand that they had been systematically lied to, as mortgages went into default, it became impossible to determine the value of debt, the security of the

14. "The Real Debt Prison in United Arab Emirates UAE," DebtPrison.net, 3 February 2009, accessed 21 February 2011, http: //debtprison.net/wordpress/297/the-real-debt-prison-in-united-arab-emirates-uae/.

15. Steve Rhode, "Bouncing a Check Can Put You Behind Bars for Years in Dubai," How to Get out of Debt, 14 September 2009, accessed 30 October 2010,

http: //getoutofdebt.org/7891/bouncing-a-check-can-put-you-behind-bars-for-years-in-dubai.

16. Barbara Surk, "Jail Time is Cost for Not Paying Debts in Dubai," The Seattle Times, 12 June 2007, accessed 30 October 2010, http://seattletimes.nwsource.com/html/nationworld/2003744014_debtors12.html.

17. See, for example, the comments to "Personal Letter from Simon Ford, bluebanana.com," arabianbusiness.com, 24 June 2009, accessed 30 October 2010,

http://www.arabianbusiness.com/simon-ford-s-emotional-letter-in-full-16770.html. 
reserves, the capacity for the banks themselves to meet their obligations. This ripple of unknowness spread, casting a shadow over all potential credit operations. Speculative markets, especially those highly-dependent on credit, immediately became poor investments. Construction companies began to abandon Dubai and it's artificial archipelago, and the unfinished skeletal buildings now haunt the horizon. Job opportunities were canceled; workers were laid off.

But this is not the point of contention. Knowing this, many still expected those who broke their word to pay off their loans. Many of them were themselves ashamed or disappointed at their inability to pay. ${ }^{18}$ For although the will of each one of them was thoroughly constellated by global economic forces, the promises they made nevertheless retained some sense of individual responsibility. Though their pens were forced, the words formed by the ink were their own. And certainly this will was not wholly imaginary; for though the individuals had only a little control over the circumstances of their lives and the possibilities for their promises, still they must have deliberated before saying "yes" to the loans which were presented to them. And in this little fraction of will they became implicated in the entire system. It is here that the bodies, ruled over by economics, become the subjects of the system.

The promise is constructed by as little as the words "I do," in response to a long train of rehearsed and prescribed text. This, in fact, is not the exception, but the

18. Subramani Dharmarajan, "Unbearable Demands: Broken Promise," gulfnews.com, 23 October 2008, accessed 30 October 2010, http://gulfnews.com/news/gulf/uae/general/unbearable-demands-broken-promise-1.459654. 
paradigmatic example. People together chant through the text of an oath, and the power of the words to compel and illustrate compulsion is made all the more powerful by the worldliness of these words, their participation in repetition, resonating with the actions of their ancestors, spoken along with their fellows, as if the speakers shared not only the bond expressed by the words but also the voice that spoke them.

The necessity, possibility, effectiveness, and feasibility of any promise is largely determined by the larger social situation. Our promises are often side effects of a towering wave of social activity, overcoming us and turning our individual lives into the instruments of larger social structures and institutions. Yet this fact makes each promise no less effective in representing the thoughts, actions, and responsibilities of an individual.

\subsection{The Question of the Promise}

In these three stories, we have three poles along which promises act: privacy/recognition, sovereignty/subjection, and individual/society. The promise always implies these poles, and is largely responsible for creating them.

Along the pole of individual/society, we find questions about the nature of the individual and her actions. A promiser gives up her freedom of choice in certain actions to others, creating social bonds in the process. These actions lose their arbitrary character and the individual becomes ethically responsible for them. The subsequent negotiations between promiser and promisee create a space in which their relative power is determined. Though this negotiation occurs with all social bonds, with the promise it acquires an 
additional characteristic: because the promise is somehow always a choice of an individual — even if that choice is largely theoretical and not actual—these power negotiations between people play out against a backdrop of one's struggle with oneself to gain self-control and self-mastery. For example, financial issues between a borrower and a lender are often framed as a question of the borrower's ability to resist the temptation of credit. As the struggle for self-mastery is played out amidst a power struggle between individuals, these two struggles overlap, and hence the socially-defined nature of the promise is able to partially determine the nature of self-mastery, and thus the nature of the individual generally.

Along the pole of privacy/recognition, we find questions about the proper function of words and acceptable processes of interpretation. A promise creates an image of the externalization of the will into language, and would not function without this image. As such, promises form a bridge between private and public. They create a public world out of otherwise private acts, and they create these private acts themselves as a corollary of their exclusion from or transformation into the public. Further, the honesty of a given promise — and hence its truth—must be able to be publicly, if not legally, determined; otherwise the promise is meaningless, not dishonest. That is, for a promise to function at all, whether it has been broken or not must be publicly decidable. This socially-defined practice of determining meaning creates a limit on what publicly true general theories of meaning can be formulated, and hence largely determines the general process of interpretation in a given society.

Lastly, along the pole of sovereignty/subjection, we find questions about the extent 
and possibility of human freedom. Every promise decouples the moment of intention from the moment of execution. Without this gap, without a socially recognizable difference between intention and execution, between sovereignty and subjection, the question of freedom cannot be socially understood. And yet the extent of our freedom depends on reuniting these moments, on recovering their lost unity. Further, because the viable modes of expression of a promise and the understanding of that expressed nature are bounded by social protocols, our intention can be taken away from us even as it is sanctified in its expression. Our freedom and our understanding of freedom within a given society depends, then, on two factors. First, the extent to which we recognize ourselves within the possible modes of expression and fulfillment in a given society, the extent to which we can be sovereign in the act of promising. Second, the extent to which our potential sovereignty reaches its fulfillment, the extent to which the world and we ourselves are capable of subjection, the extent to which our promises can be kept.

As the story of Dubai illustrates, every action we perform is social and is constellated with the necessities of our social and material situation. Which promises are possible or necessary is determined by countless other factors, other promises not least among them. The very personal questions the promise puts forward-what we can express and how, what we are as individual beings, and to what extent we are free-these are answered amidst a tumult of other voices and actions. The answers can neither be imposed from above, nor decided individually, but instead largely depend on the greater social structure of a society. The promise, then, is an extremely important site for the study of materialism. 
If we are to take hold of these questions, if we are to consciously take part in the struggle to determine what we mean, what our nature is, and the extent of our freedom, then we must take hold of the way we promise. We must promise with a consciousness of the promise's effects, aware of the implications of not only this promise, but the general structure of promising with which we are participating. We must transform the social structure of the promise to make room for the promises we would like to see. And in order to do all this: we must understand the promise; we must understand its relationship with the structures of a society; and we must understand how it changes as a society changes. This thesis is a step towards that understanding.

\subsection{Other Theories: Nietzsche}

Though I hope to make an original contribution in my particular claims, I certainly can't claim to be the first to study the promise. Of the various texts that have influenced this study, Nietzsche's On the Genealogy of Morality is the most important. Before beginning the main part of this study, I will briefly address my reading of Nietzsche and another way of looking at promises that is particularly influential and widespread, the speech-act theory of J.L. Austin.

Nietzsche was the first to capture the tension between the two sides of the freedom offered by the promise. In what is in many ways a response to the social contract tradition, the second essay of Genealogy of Morality presents us with a double theory of the promise. On the one hand, Nietzsche talks in no uncertain terms about the value of the 
promise:

Let us place ourselves, on the other hand, at the end of this immense process where the tree actually bears fruit, where society and its morality of custom finally reveal what they were simply the means to: we then find the sovereign individual as the ripest fruit on its tree, like only to itself, having freed itself from the morality of custom, an autonomous, supra-ethical individual (because "autonomous" and "ethical" are mutually exclusive), in short, we find a man with an independent, lasting will, who may promise - and in him a proud consciousness quivering in every muscle of what he has finally achieved and incorporated, an actual awareness of power and freedom, a feeling that man in general has reached completion. ${ }^{19}$

The ability to promise is linked with the "sovereign individual [souveraine Individuum]," such that the two are almost identical, for because of this ability to promise, a human now has "an independent, lasting will," that is, a will that can be extended over time. The promise thereby serves as a platform for our greater power, no longer simply power over a moment, but power over time. Further, with this extension over time, the ability to promise gives that will consistency, and so instead of discrete moments of the will, we have a holism, a "sovereign individual."

But on the other hand, as Nietzsche says, "that particular task of breeding an animal who may promise includes [...] as a precondition and preparation, the more immediate task of first making man to a certain degree necessary, uniform, a peer amongst peers, orderly and consequently predictable." ${ }^{20}$ Uniformity is the loss of individuality; necessity is the loss of sovereignty; and so the fruit of the promise is exactly the opposite

19. Friedrich Nietzsche, On the Genealogy of Morality, trans. Carol Diethe (Cambridge: Cambridge University Press, 2007), 36, II, 2. I have made minor changes to the translation.

20. Ibid., 35, II, 2. 
of its precondition. The promise has two opposing modes, and if we are to create the sovereign individuality of the promiser, paradoxically, we must also accede to its opposite.

Nietzsche presents the sovereign individual as the future, and the necessity and uniformity that individual requires as the past. However, though there might be some truth to this order of development buried in prehistory, I would argue that the tension between these two sides can never be resolved in any sort of supersession, but can only be temporarily configured into an uneasy truce. To qualify as a promise, every promise must have both a moment of formation, and a fulfillment that takes place over time. The bare existence of these parts is not historical, though their particular expression is. As one creates a promise, one acts as the sovereign; but as time passes, the promiser must lapse from sovereignty to subjection, and what was free will must lapse into necessity. The two are dependent on one another, and if one would be sovereign over herself, one must accede to a certain subjection. As both the presence of subjection and the lack of sovereignty are ultimately unacceptable, this border between sovereignty and subjection produces a constant and continuous negotiation which takes on different forms at different historical moments.

\subsection{Other Theories: Speech-Act Theory}

In How to Do Things with Words, J.L. Austin argues that in addition to "constative" language (or towards the end of the book, instead of "constative" language), there is a type of language which he calls "performative." When a performative phrase is 
uttered, according to Austin, one does not merely express something, but performs some sort of action. The promise is perhaps his paradigmatic example. When one says "I promise that..." then, according to Austin, one does not merely state a fact but actually enters into a promise; the promise itself is formed through the words-though there may be other necessary factors accompanying those words as well (for example, that one does not speak these words within the context of a play). ${ }^{21}$

This is not wrong, but it is extremely modern. This can be seen particularly with the way Austin summarily deals with his opposition:

Surely the words must be spoken "seriously" so as to be taken "seriously?" $[\ldots][\mathrm{W}] \mathrm{e}$ are apt to have a feeling that their being serious consists in their being uttered as (merely) the outward and visible sign, for convenience or other record or for information, of an inward and spiritual act: from which it is but a short step to go on to believe or to assume without realizing that for many purposes the outward utterance is a description, true or false, of the occurrence of the inward performance. ${ }^{22}$

Austin quickly dismisses this as it would lead to the situation where someone could deny that a promise had been made, even though this promise had been communicated. ${ }^{23}$ But the characteristics of the opposition that Austin lays out here-the nature of intention and its relationship to the "visible sign" and the "spiritual" being of the speaker - these are what is at stake in the history of the promise.

What is constantly at issue within the figure of the promise, and cannot ever be fully resolved, is the way that the promise must both be related to subjective intention in

22. Ibid., 9.

23. Ibid., 10. 
order to be valid, and nevertheless must also take place within the realm of public discourse and action. Austin's solution, and the modern solution, is to deliberately conflate the subjective intention with language itself, thus wholly reducing the subjective component of the promise to the choice of what words to utter, to the choice of the act of speaking, signing, etc. In contrast, during most of the medieval period in Europe, the primary linguistic record of a promise (a notarial record or a document under seal) would not be written in the promiser's own hand, nor would it record the promiser's literal words. Rather, it would record exactly what Austin is claiming to be secondary to the promise: the intention. The promiser would speak his promise in the vernacular, then a scribe would record what he intended to promise in Latin, then witnesses would attest that this was indeed his intention.

The theory of performativity, then, is a particular encapsulation of some of our modern views on language, subjectivity, the public, and the relationships between these three. As such, it is extremely useful. But if one thinks of the promises I describe in this thesis as always-already performative in the Austinian sense, then the historical transformations these promises undergo will be largely missed.

\subsection{A Note on Historical Investigation and Method}

At every point in history where there has existed something like a promise-and I know of no culture that has no form of the promise-there has existed some form of negotiation between privacy/recognition, sovereignty/subjection, and individual/society. 
Though the words I use here are particularly Western and modern, this is no reason to suspect they are inadequate for describing other cultures and periods, provided that one is sufficiently careful. For example, the idea of sovereignty has been well-documented as historically bounded. ${ }^{24}$ In Feudal Europe, the pole which I have described here as "sovereignty/subjection" instead might be better described as "lord/vassal." The differences between these, of course, are vast. Lord/vassal makes sense primarily as a social relationship, whereas sovereignty/subjection, at least as I'm using the words here, designates a feature of the will of each person more than their social position. The differences between lord/vassal and sovereignty/subjection are large enough that one could be justified in treating them as entirely separate, unconnected ideas; but that's not the path I plan to take.

In the "Introduction to a Contribution to the Critique of Political Economy," Marx states:

Just as in general when examining any historical or social science, so also in the case of the development of economic categories is it always necessary to remember that the subject, in this context contemporary bourgeois society, is presupposed both in reality and in the mind, and that therefore categories express forms of existence and conditions of existence-and sometimes merely separate aspects_-of this particular society, the subject; thus the category, even from the scientific standpoint, by no means begins at the moment when it is discussed as such. ${ }^{25}$

24. See Giorgio Agamben, State of Exception, trans. Kevin Attell (Chicago: University of Chicago Press, 2009). Also, see Michel Foucault, Security, Territory, Population: Lectures at the College de France, 1977-1978, ed. Michel Senellart, trans. Graham Burchell (New York: Picador, 2007).

25. Karl Marx, "Introduction to a Contribution to the Critique of Political Economy," Marxists Internet Archive, last modified 2009, accessed 7 June 2010,

http://www. marxists.org/archive/marx/works/1859/critique-pol-economy/appxl.htm, Marx's emphasis. 
That is, whatever categories we bring to historical analysis - the example Marx uses in the text quoted is "labour as such," that is "neither manufacturing, nor commercial, nor agricultural labour, but all types of labour"26_are our categories, and make sense primarily in our place and time. It is true that when these categories are applied, they color the past and disturb "unmediated" access. But the mediation they imply is itself the goal of historical inquiry. As a result of applying categories that make sense in the present to the analysis of past texts, what we obtain is a genealogy and understanding of objects that presently exist. If, conversely, we were to shun this mediation and let the objects of the past determine their own categories — if such a thing were even possible, that is — what we would obtain is a history consisting of absolutely disjoint periods, each mutually incomprehensible and incomparable to the others, where no coherent understanding of their relationships could be formed.

It may be true that on a certain "objective" level that this is the truth with which history presents us, that history consists of a set of mutually incomprehensible and incomparable eras, and the idea of transition is merely a myth. But to try to align whatever truth we search for in history with this type of objectivity is to forget the nature of the questions we began with, all of which seek to understand the potential for transition in the present, and what form that transition might take, from the point of view of a human for whom coherence and conscious action are a necessity. Because of this, we have no choice but to stretch each category of analysis across both past and present, whatever the

26. Ibid. 
The Promise: Historical Investigation and Method 20 distortion from the "objective" this might produce. For this "distortion" is not distortion at all, but the requisite transformation by which objects are changed into knowledge. Only by this transformation can we bridge the space between historical data and present understanding. 


\section{The Formation of the Modern Promise in the West}

\subsection{Historical Overview}

In the context of Western Europe, the promise begins as a direct, person-to-person ritual, emphasizing intention, meaning, witnesses, the sacred, and interpersonal bonds. In the present global context, the promise has become an indirect, impersonal ritual, emphasizing signifiers, the written word, and legal structures. The history of the Western promise is therefore a history of the gradual march from direct to indirect, from spoken to written, from intention to literal meaning, and from personal to impersonal. Roughly, this history can be divided into three main periods: from prehistory until the development of notarial services, from the development of notarial services until the appearance of negotiable instruments, and from the appearance of negotiable instruments up to the present ubiquity of computer-aided credit operations. In this thesis, I will be dealing with the way the promise changed with the rise to dominance of the negotiable instrument.

It will be noted that these categories, although not always exclusively fiduciary, mostly revolve around questions of debt and credit, especially monetary debt and credit. The fiduciary promise is a particularly interesting site, as its relation to our economic practices is easily evident. But the history of the fiduciary promise does not comprehensively encompass the history of the promise itself. In particular, marriage vows and oaths of allegiance are conspicuously absent. Arguably, both of these are more important for the economy and the power structures of medieval Europe than are the promises which revolve around finance. In some ways, then, this history should not simply 
be about the transitions of a fiduciary mode of promising, but also about a transition to a fiduciary mode of promising. For practical reasons, however, this must be left for another project. In any case, it is my contention that different types of promises largely determine each other, that is, that the need for consistency accompanies our social practice of promising. Therefore I expect that the history of the marriage vow or the oath of allegiance would not yield a fundamentally different conclusion than what I have here, though one would certainly expect to uncover additional conclusions.

Negotiability is the mark of the dominant mode of the promise from the sixteenth to the twentieth century. For a promise to be negotiable, it must be transferable in a specific way. A negotiable instrument is a paper bill, a written promise, that is legally both assignable and transferable. That is, transferring the instrument confers both the right to the benefits and the right to legal recourse if the promiser refuses to honor the instrument. Further, negotiability, in its technical sense, implies the right of recourse not just against the original promiser but also against each person in the chain of assignors who passed the bill to the next person. Each assignor is liable for the value of the instrument. Before the date at which the bill becomes due, a negotiable instrument is often discounted, that is, sold for less than its nominal value. This practice is what creates a market out of assignable promises, with futures contracts and other exchange-traded derivatives.

With the appearance of the negotiable instrument, the practice of promising was radically altered. As I will argue, because the promise was transferred with the instrument, the practical distinction between the promise and the instrument that describes it began to decay. With the decay of this distinction, legal writing, before almost wholly evidentiary 
(merely recording actions), became predominantly dispositive (creating actions). ${ }^{1}$ Further, because it could be discounted, the risk inherent in any negotiable instrument was given a definite exchange value, and the individual will became something that could be bought and sold. As I will explore in chapter 3, the transformation of the promise with negotiability led to a change in the character of written language, giving rise to both a new type of language with a fixed interpretation, the modern fact (a term I owe to Mary Poovey, see section 3.2), as well as a new type of language with a fluid referent, the algebraic variable.

\subsection{Before Negotiability}

Prior to the creation of the negotiable instrument, keeping your promise largely meant adhering closely to a script within a predefined relationship. One would momentarily take on a role within an interaction, and the result would be legally binding because the promise accorded with the order of society. In English common law, for example, this could be seen in the dominance of the use of the action of debt rather than covenant. $^{2}$ What was proven in court was not that someone promised some specific thing, but that the defendant stood in a debtor relationship to the plaintiff. The creation of the debtor-creditor relationship was the result of the promise to pay, but it was primarily

1. For a discussion of these, see A.W.B. Simpson, A History of the Common Law of Contract: The Rise of the Action of Assumpsit (Oxford: Clarendon Press, 1975), 15-17.

2. Simpson, A History of the Common Law of Contract, 17-18. 
through this relationship that the promiser was bound, and not through the specific words that created that relationship.

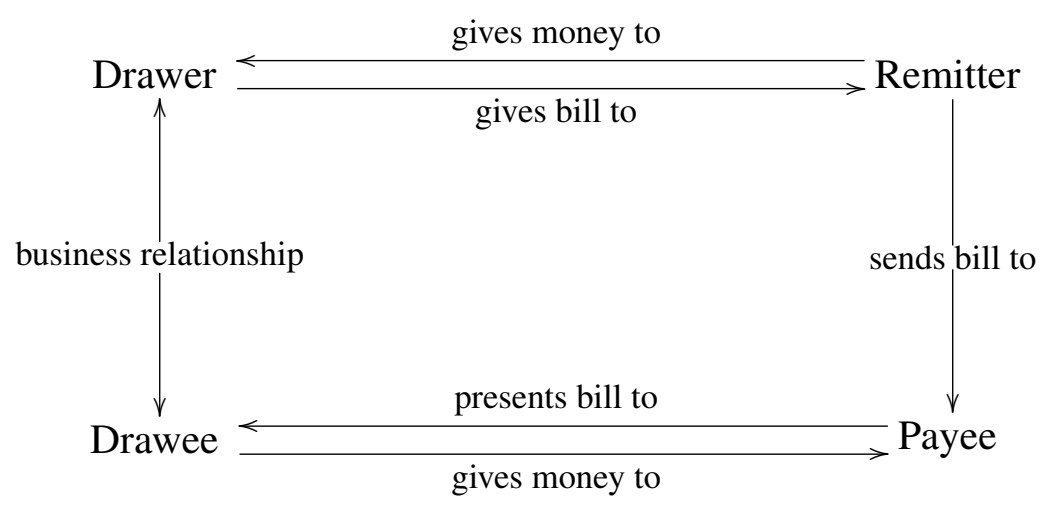

Figure 2.1: The Parties in a Transaction via Bill of Exchange

The bill of exchange, the dominant financial instrument in Europe prior to the inception of negotiability, was conceived of exactly along these lines. There were four parties to a bill of exchange, the drawer (prenditore), the remitter (datore), the drawee (pagatore), and the payee (beneficiario) (see Figure 2.1). The process began (at least theoretically, as we shall see) when the remitter, residing in one place and using one currency, wished to transfer money to the payee, residing in another place and using another currency. The remitter would approach a merchant banker (the drawer) who had an associate in another city (the drawee). For a specified price, he would purchase a bill of exchange from the drawer, payable by the drawee to the payee in another currency. He then would send it to the payee, usually in several copies, or possibly give it to him in person if this was part of a trade transaction with a traveling merchant. Upon receipt, the payee would present the bill to the drawee, and after it was accepted, the drawee would have a specified period of time to pay the payee his due. This period was usually "usance" 
or "double usance," usance being a customary period varying with the distance between the two cities. Bills of exchange were not transferable, though as we will see, the debt which they represented was. The instrument was an order to pay a particular person, and the identity of this person was fixed upon the creation of the instrument. ${ }^{3}$

In practice, a bill of exchange was only rarely an operation whose sole purpose was transfer. For example, a merchant banker wishing to purchase goods could play the part of both drawer and drawee and sell a bill of exchange in order to obtain the funds to make his purchase. He would then repay these funds in another city at another time in what was effectively a loan. Because of the delay inherent in the usance period, it was also possible to use the bill of exchange as a purely financial instrument. In this case, a merchant banker with cash to spare (the remitter) would loan this cash by purchasing a bill of exchange from someone wishing to borrow cash (the drawer). The remitter then would send the bill to his agent in another city, where the payee-the remitter's agent, or sometimes the remitter himself-would obtain the agreed-on amount in another currency from the drawer's agent, the drawee, after the usance period of the bill had expired. Then the remitter's agent, the payee, would find someone who wished to draw a bill of exchange on the same city as the original remitter. The roles would then be reversed for a second bill of exchange, with the original payee as the remitter, and the original remitter as the payee. After two exchanges between two currencies, extended over two cities and a

3. The best recent general discussion of the bill of exchange can be found in Markus A. Denzel, "The European Bill of Exchange," in Cashless Payments and Transactions from the Antiquity to 1914, ed. Sushil Chaudhuri and Markus A. Denzel (Stuttgart: Franz Steiner Verlag, 2008). The most comprehensive is still Raymond De Roover, L'Évolution de la Lettre de Change, XIVe-XVIIIe siècles (Paris: Librarie Armand Colin, 1953). 
period of time, the original remitter (now the payee) would find himself in possession of the same money he started with, plus what was effectively interest worked into the two exchange rates. The two halves of this transaction were known as cambium (exchange) and recambium (re-exchange). ${ }^{4}$

This doesn't exhaust the possible uses of the bill of exchange, but what is important to note is that, although the effective relationships change depending on whether one is sending money, performing a financial transaction, selling goods, etc., the nominal relationships are fixed to these four roles. The structure of the bill was so rigid that even when there are three rather than four participants, there are still four roles, though one person acts in two of these roles. For example, the following was effectively an order for a book transfer:

In the name of God, 25 February 1400

Pay for this second letter if not for the first[.] Pay at usance to you yourselves lb.420 Barcelonese, of which lb.420 are of the good money that is here by Giovanni Orlandini and Piero Benizi and Company. Make good on the payment and put in my account. May god protect you.

Ghuiglielmo Barberi Salute of Bruges

[On the Back:]

Franciescho di Marcho and Company

in Barcelona

Second $^{5}$

4. See Raymond de Roover, "What is Dry Exchange? A Contribution to the Study of Mercantilism," in Business, Banking, and Economic Thought in Late Medieval and Early Modern Europe: Selected Studies of Raymond de Roover, ed. Julius Karshner (Chicago: The University of Chicago Press, 1974). But for a somewhat different account of financial operations with bills, also see Marie-Thérèse Boyer-Xambeu, Ghislain Deleplace, and Lucien Gillard, Private Money and Public Currencies: The 16th Century Challenge (Armonk, NY: M.E. Sharpe, 1994).

5. My translation, from Raymond de Roover, Money, Banking, and Credit in Mediaeval Bruges: 
Because the payment was between two accounts at the same bank, the bank was both drawee and payee. The recipient of the letter played two roles, so rather than change the number and nature of the relationships through changes in the bill, the order to transfer became an order to "pay to you yourselves [paghato a voi medesimo]."

For a bill of exchange, the paper and the language functioned like props in a play. The players would take on the proper roles and make use of these props, but their existence as props was more important than their specific character. One was somewhat free to move between roles and even to reinterpret those roles within limits, but roles could not be created from nothing. By the sixteenth century, the written text of these bills began exhibiting a meaning beyond what these traditional roles gave to it; but until then, this meaning was present, but partial, only gradually developing into something greater than a prop.

Italian Merchant-Bankers, Lombards and Money-Changers-A Study in the Origins of Banking (Cambridge, MA: Mediaeval Academy of America, 1948), 58.

"Al nome di Dio

dì 25 febraio 1400

"Pagharete per questa seconda lettera se per la prima non avessi paghato al usanza a voi medesimo lb.420 barzalonesi, le quali lb.420 sono per la valuta sono qui contento da Giovanni Orlandini e Piero Benizi e compagni. Fatene buon paghamento e ponete a mio conto. Che Idio vi ghuardi.

"Ghuiglielmo Barberi Salute di Brugia

"[On the back:]

\footnotetext{
"Franciescho di Marcho e compagni

"in Barzalona

"Seconda."
} 


\subsection{The Transition to Negotiability}

Though negotiability was later applied to the bill of exchange, it did not begin

there. Instead we find its origin among a different credit instrument used by the merchants

of northern Europe (primarily in England and the Low Countries): the promissory note.

This is a typical example:

Let it be known to all, that I, Robert Tylney, a merchant of Bishop's Lynn, am beholden and firmly obligated to Henry Foster of Newark, draper, for the sum of seven pounds of good and lawful English money, to be paid to the said Henry, his heirs or executors or to his certain attorney at the next Feast of the Translation of Saint Thomas the Martyr after the present date, without further delay. And for that said payment which should be well and faithfully made, I oblige myself, my heirs and executors, and all my present goods. ${ }^{6}$

This bill forms an intermediate link between the dispository and evidentiary

traditions. Just as a notarial record would be written as a third-person narrative, the author here is declaring the existence of the obligation in the document- "let it be known to all [noverint universi]"- just as much, if not more, as he is forming the obligation by means of the document- "I oblige myself." The payment is formulated almost as an order to himself, similar to language that would have been used in a bill of exchange: "to be paid to the said Henry, his heirs or executors or to his certain attorney." Nevertheless, as a note usually written in the promiser's own hand, the promissory note was a more personal

6. My translation, from M.M. Postan, "Private Financial Instruments in Medieval England," in Medieval Trade and Finance (Cambridge: Cambridge University Press, 1973), 30. "Noverint universi me Robertum Tylney de Lenn Episcopi mercatorem teneri et firmiter obligari Henrico Foster de Newark draper in septem libris bone et legalis monete Anglie, solvendi eidem Henrico, heredibus vel executoribus suis aut suo certo attornato in festo Translacionis Sancti Thome Marti[r]is proximo futuro post datam presencium, sine dilacione ulteriori. Ad quam quidem solucionem ut predicitur bene et fideliter faciendam, obligo me, heredes et executores meos ac omnia bona mea per presentes." 
document than previous instruments, and in the absence of a witness, the promiser's own handwriting could serve as evidence, further giving the bill a dispository character.

The phrase "or to his certain attorney [aut suo certo attornato]" was also typical of promissory notes, sometimes taking the form "or to the bearer of this letter," and although less frequently, would also sometimes be present on a bill of exchange. For the most part, this addition seems to have been for the purpose of allowing some servant or associate of the creditor to collect the debt on his behalf, and not for the purpose of transfer. ${ }^{7}$ Sometimes the bill itself would actually be transferred to a third party, but this phrase "to the bearer" did nothing to improve the legal standing of the person to whom the letter was transferred, who would still only have recourse through a suit brought by the original creditor. $^{8}$

Regardless of the document used, or even the lack thereof, practically speaking debts were frequently transferred throughout the Middle Ages, often so that the debtor would have his own debt returned to him as payment for other debts owed to him. In this way, each person's debts against others formed a sort of private banking system, though unlike a book transfer of funds, the transfer of debt did not clear one of his obligations until the debt was actually paid by the debtor. ${ }^{9}$ Thus if a debtor transferred a debt to his

7. James Steven Rogers, The Early History of the Law of Bills and Notes: A Study of the Origins of Anglo-American Commercial Law (Cambridge: Cambridge University Press, 1995), 173-174. De Roover, L'Évolution de la Lettre de Change, 87. Postan, "Private Financial Instruments in Medieval England," 52-53.

8. Postan, "Private Financial Instruments in Medieval England," 53.

9. Herman Van der Wee, "Antwerp and the New Financial Methods of the 16th and 17th Centuries," in The Low Countries in the Early Modern World, trans. Lizabeth Fackelman (Aldershot, Hampshire, UK: Variorum, 1993), 152-153. 
creditor but the debtor whose debt was transferred failed to pay, the creditor could demand payment from the debtor who transferred the debt to him. Instead of this informal process, a formal document, a cessio, could be produced, ceding the debt to another. In this case, the recipient of the cessio would receive full legal right to the debt, and he could sue in his own name, rather than having to turn to the creditor who transferred the debt. However, the recipient would also receive the full risk of assuming this right, as the former holder would be considered quit of his own debt upon the creation of the cessio. ${ }^{10}$

This system of debt transfers indicates two different attitudes towards the transfer of debt. If one transferred the debt without a formal document, this was something in between a payment by proxy and an actual transfer of debt. A creditor would pay his own creditor, but rather than doing it directly, he would do it through his own debtor. This concept of payment by proxy was reflected in the lack of a legal right to the debt by the transferee, as well as the possibility of recourse against the creditor who transferred the debt. However, as early as the fifteenth century the practice was already leaning towards transfer, as some bills would pass through as many as five or more hands without a formal document transferring debt. ${ }^{11}$ If, on the other hand, one transferred the debt with a formal cessio, the situation was identical to a cancellation of the previous debt and the creation of a new debt. The debt itself was not transferred; the role of the creditor was passed on to another person. The original creditor, the new creditor, and the debtor all had to attest to 10. Ibid., 152. 11. Postan, "Private Financial Instruments in Medieval England," 41-42. 
the new debt relationship that was being formed to replace the old one.

The passage to negotiability began with a reinterpretation of the "to bearer" clause. In Antwerp, in 1507, a tourbe-the testimony of a group of prominent merchants-explicitly stated before the Antwerp magistrate that when a document was made out to the bearer, it was the custom for this bearer to have full rights to the debt and be able to sue on his own behalf. ${ }^{12}$ It is an open question whether this actually testified to a custom that was becoming widespread at the time, or whether the tourbe created that custom by fiat. John Munro, at least, believes this development to have begun in England with the case of "Davy v. Burton" in 1436, though if this ruling indicates that debt instruments were transferable at the time, there are many other indications that there must have been a gap in the validity of transfer in England before the early seventeenth century. ${ }^{13}$ Regardless, following on the 1507 decision, an imperial dictum of 7 March 1537 generalized this principle throughout the Netherlands, and after this the transfer of bills proliferated throughout the region. ${ }^{14}$

At first, this reinterpretation of the instrument barely altered current practice, taking the place of the system of transferring debts by a cessio. As such, there remained certain financial advantages against accepting this type of payment: the transfer by bill

12. Herman Van der Wee, "Antwerp and the New Financial Methods of the 16th and 17th Centuries," 152.

13. John Munro, "The International Law Merchant and the Evolution of Negotiable Credit in Late-Medieval England and the Low Countries," in Textiles, Towns and Trade: Essays in the Economic History of Late-Medieval England and the Low Countries (Aldershot, Hampshire, UK: Variorum, 1994), 71-75. 
was considered final payment, regardless of whether the debtor named on the bill paid his due when the time came. ${ }^{15}$ In order to fully replace the utility of the previous system of debt transfer, the bill needed to function as a payment; that is, one needed the right to legal action if, for whatever reason, the value of the bill was other than what it purported to be. What this means is that the obligation, the promise, had to be equated with its ultimate value, that is, its fulfillment. The will itself had to be given a value, to become a commodity. This shift in attitude followed within the first century after the inception of negotiability. First, the financial liability of those passing on bearer documents was asserted, and their names were recorded by the participants in separate documents. Soon, however, these names began to be written on the back of the bill (Latin, in dorsum) as a sign of the transfer itself, and by the mid-seventeenth century, the practice of endorsement was more or less established in most of Europe as it functions today. ${ }^{16}$

\subsection{Further Developments}

By the early seventeenth century, the principle of negotiability had been applied to the first joint-stock company, the Dutch East India Company or VOC, and shares were being continually traded in the Amsterdam bourse. ${ }^{17}$ In England as the civil war was brewing, Charles I forcefully "borrowed" all of the money a large number of merchants

15. Ibid., 152.

16. Ibid., 157-159.

17. Fernand Braudel, Civilization and Capitalism, 15th-18th Century: The Wheels of Commerce (New York: Harper and Row Publishers, 1982), 100-106. 
had been storing in the tower of London (the money was, in fact, repaid), and in response the merchants sought a private means to store money with those who already had vaults secure enough for the purpose: the London goldsmiths. The goldsmiths would issue promissory notes for a deposit, made out "to bearer." Soon thereafter these began to be used as currency, in place of specie. When the Bank of England drove all the local goldsmiths out of business, it continued this practice, issuing Bank of England notes to all of its customers. ${ }^{18}$ Though none of this qualitatively altered the promise as it was established with negotiability, the ubiquity of paper money nearly universalized it.

This situation remained more or less unchanged until the Great Depression, when the promise to repay in gold was revoked in most countries. The paper then became valuable not because it promised gold—-though that promise had long ago become rather abstract—but merely because it was mutually accepted. At the same time, with the inception of Keynesian economics, governments began to stand in for their constituents by obtaining what were effectively loans on their behalf. Along with the other Bretton Woods institutions established at the end of World War II (the International Monetary Fund and World Bank), an international gold standard was established whereby the dollar would be pegged to a certain amount of gold, and all other national currencies would peg themselves to the dollar, keeping dollars as reserves. In the 1970s, Nixon abolished this last stronghold of gold, stating that the United States would no longer give gold out in exchange for dollars. Thus most countries entered into a system of fiat money, where

18. William Dodgson Bowman, The Story of the Bank of England, from Its Foundation in 1694 until the Present Day (London: H. Jenkins, Limited, 1937). 
money has value simply because of a declaration — although the counterfactuals implied by reserves in the form of gold or dollars, as well as a government's explicit acceptance of their own money for tax purposes, plus enforcement against the issuance of alternate currencies, all paint a much more complicated picture than fiat might imply.

Recently, with the domination of credit cards, credit reports, and electronic transfers, we are seeing the largest shift in the nature of promises since the development of negotiability. Increasingly trust is brokered not by individuals, but by closed-source computer programs controlled by corporations - the Fair-Isaac Corporation (FICO) Score in the United States. Rather than our writing or our signatures providing the embodiment and authenticity of value, both value and credit are increasingly obtained by the knowledge and use of a sixteen digit number-though some would say this is soon to be replaced by smart cards utilizing public-key cryptography, in which case everything about the use of credit will depend on the possession and correct functionality of what will most likely be closed-source computing hardware. On top of this, the ubiquity of the End User License Agreement (EULA) — a document, electronic or paper, that claims to take effect the moment you use a purchased item, whether you've read it or not, whether you were responsible for obtaining the item or not-may further affect our environment of promising (though as of 2011, the litigation over EULAs is sparse enough that many aspects remain unclear).

So far, we have lived through the transitions of the promise passively. Without understanding, the iron bars of history form a cage, and we are trapped in a cycle of misunderstanding and unforeseen consequences. With understanding, what seemed like 
the bars of a cage becomes the rungs of our playground. Though most of the recent changes in the mode of promising are alarming, what they mean is largely yet to be determined. I won't explicitly address these changes in this thesis, but as I examine the historical situation, they are in mind. It's my hope that with a better understanding of the promise, we can formulate a practice of promising and take part in this development, helping to determine what it means and how it will work, rather than passively becoming its victims. 


\section{Signification and Algebraic Language}

\subsection{Fixed Meaning, Fluid Meaning}

With the inception of the negotiable instrument, a type of language is created that is simultaneously more fixed and more fluid than in previous periods.

As the negotiable instrument is a commodity, in this instrument the promise is reified in the same way as any other commodity. Just as in commodity fetishism the productive relationships of a given society are reduced to a relationship between objects, so with the negotiable instrument the complex debt relationships between people are reduced to purchasable inscriptions on an object. This is by far the dominant mode by which a negotiable instrument functions, with all of the complexity reduced to the purchase and transfer of paper. When whoever is responsible for the instrument cannot be made to fulfill their obligation to the presenter of the bill, however, the use of the instrument as a fetish breaks down and the relationships become relatively clear. But this possibility is quickly forgotten in practice, for unless one is currently engaged in litigation, one's relationship with the negotiable instrument is a commodity relationship.

Because its status as a commodity causes the negotiable instrument to appear to be self-sufficient, the function of the witness is suppressed, as it is necessarily separate from the bill. In place of the witness, we are left with nothing but the text itself. Any other conception of meaning requires one to think outside the bounds of commodity fetishism. Without a witness, the idea of an original meaning is no longer tenable; theoretically, all sufficiently skillful interpreters of a bill are equal. The long list of assignations scrawled on 
the back is not so much a list of these interpreters as a list of those who will vouch for the bill's interpretive self-sufficiency. The equality of the legal position of each interpreter, the lack of priority given to the first assignee, also implies a meaning that preexists this list.

Meaning in a negotiable instrument is the meaning of a simulacrum, a copy without an original. Fixed by a tradition of interpretation that eschews the individual witness, the object means according to its customary use, for though a singular ad hoc negotiable instrument is not unheard of, it is the exception. As the negotiable instrument becomes reified, a form of writing is created whose meaning is decided by its status as a simulacrum, by the practical transactions in which it is customarily involved, yet which simultaneously appears to be self-contained, its own originator, independent of tradition. Negotiability thereby creates a form of writing for which the process of interpretation is largely hidden and claims not to exist at all: namely, the modern fact.

At the same time as the meaning of words in a negotiable instrument becomes fixed into a fact, it also tenuously floats above its referent. To bearer or to order, having no valid referent at the time of writing, can be determined at a later date, upon presentation of the bill. The meaning of the words are no longer fixed by the immediate agreement of speaker and witness, but can be determined by others, at any time or place. Here we see the development of a new type of abstraction. To bearer is an intentionally dangling referent. It partakes of the same sort of abstraction that the legalistic phrase "said..." does (as in "the said document"). It is a definite reference rather than an indefinite meaning. And yet the independence of the text from the interpretation of an originary witness means that this definiteness is yet to be determined. To bearer and to order function as the 
legalistic said in reverse: they defer final meaning to a future explanation. What we are seeing here is the development of the symbolic variable: a sign which signifies according to its possibility of reference, not its actuality.

Fixed meaning and fluid meaning are not two opposing developments, but are only two seemingly opposed characteristics of the same development. In the course of the sixteenth and seventeenth centuries, we see a profound shift in the concept of language such that all language seems to function in the same way as a symbolic variable: as a reference rather than a meaning. This development has had profound consequences on how we conceptualize the world, and has provided one of the cornerstones on which modern scientific thought is built. Here, I will only deal with a part of this development which I perceive as having a relatively clear connection with the development of negotiability: the development of modern algebra.

\subsection{Other Theories: Double-Entry Bookkeeping and the Modern Fact}

There are two theories that I should address here, as they are superficially very close to my own: Max Weber's socioeconomic theory of the rise of rationality, and Mary Poovey's theory of the development of what she calls the "modern fact." Although both are substantially different from one another, they both place particular emphasis on a mode of writing which was popularized contemporaneously with negotiable instruments: double-entry bookkeeping. (Luca Pacioli's 1494 treatise, Summa de Arithmetica, is the earliest published account of the double-entry system, though there are traces of it earlier.) 
Weber links accounting with the modern predominance of "formal rationality"- rationality with respect to the means for achieving an end (as opposed to "substantive rationality," rationality with respect to the ends themselves). Because he associates formal rationality so specifically with numbers, for Weber accounting is not so much an underlying cause of formal rationality as it is its quintessential manifestation. ${ }^{1}$ Accounting is the process of measurement and calculation which constitutes the formal rationality of a market economy. Weber places particular importance here on double-entry bookkeeping as "the most highly developed" form of accounting. His claim is that, with double-entry bookkeeping, "through a system of individual accounts the fiction is here created that different departments within an enterprise, or individual accounts, conduct exchange operations with each other, thus permitting a check in the technically most perfect manner on the profitability of each individual step or measure."2 Weber's thesis was picked up by Warner Sombart and others, who (with varying degrees of emphasis) also linked double-entry bookkeeping in a causal way with the genesis of capitalism, for double-entry bookkeeping (so the story goes) made profit and loss calculable. ${ }^{3}$

Clearly there is a certain sense in which Weber is correct: because of the necessity of accounting, capitalism requires concrete mathematical practice in a way that many other economic systems do not. However, focusing on this purely quantitative rise in

1. Max Weber, Economy and Society: An Outline of Interpretive Sociology, ed. Guenther Roth and Claus Wittich (Berkeley: University of California Press, 1978), 88-100.

2. Ibid., 92-93.

3. See B.S. Yamey, "Scientific Bookkeeping and the Rise of Capitalism," The Economic History Review 1, nos. 2 and 3 (1949): 99-113. 
mathematical practice obscures the profound qualitative changes mathematics was undergoing during the sixteenth and seventeenth centuries. Despite the central focus on formal rationality in Weber's later work, he does not rigorously analyze this concept. Weber's idea of formal rationality certainly does not seem to include the sort of reasoning that a medieval scholastic would recognize as the essence of the ratio. In fact, by equating rationality with accounting and calculation so strongly, it is clear that for Weber formal rationality is something profoundly entangled with calculation, if not synonymous with calculation.

In contrast, even as late as Newton we see the persistence of a different concept of rationality. When Newton published the Principia in 1687, the symbolic methods of calculation which are evident in his notes (namely, the calculus) were not presented. Instead traditional, pre-Cartesian, geometric proofs were presented-a non-symbolic, non-calculating rationality_for proof was still considered by some to be better guaranteed by one's mental clarity, as one conceived of a geometric idea and led that idea through various transformations, than guaranteed by the formal correctness of a symbolic manipulation. But Newton was probably more conservative than he needed to be, as symbolic calculation was already well on its way to secure a new role in thought. Though rationality in general was certainly not invented in the sixteenth and seventeenth centuries, formal rationality, as Weber describes it, did not simply see a quantitative rise during this period: the philosophical and mathematical transformations of the sixteenth and seventeenth century are the creation of formal rationality as such.

Poovey recognizes this much more clearly than did Weber. In A History of the 
Modern Fact, Poovey traces the development of a discourse that separates description from interpretation, where the description "seem[s] preinterpretive or even somehow noninterpretive."4 This type of description is what Poovey calls "the modern fact." Though Poovey is careful not to equate double-entry bookkeeping with the origin of the modern fact, double-entry bookkeeping is particularly important in her work, as it shows us an early prototype of the modern fact that already exhibits most of its essential characteristics. For Poovey, double-entry bookkeeping is a rhetorical fiction that by effacing the details of the so-called memorial - the journal-like account book that is used to write down detailed accounts of transactions as they occur-is able to construct a representation that consists only of numbers and terse labels, fictitiously balanced through mathematical manipulation. ${ }^{5}$ Writers of this period worked hard to create the objective noninterpretive character of these terse numeric representations in distinction with the detailed narratives of the memorial.

Though my conclusions are ultimately the same as Poovey — that double-entry bookkeeping illustrates a transition to the modern fact-I give considerably less importance to double-entry bookkeeping with respect to the modern fact's development. It should be emphasized that what we see in the early-modern period is a proliferation of instructional treatises arguing the merits of double-entry bookkeeping, not, for the most

4. Mary Poovey, A History of the Modern Fact: Problems of Knowledge in the Sciences of Wealth and Society (Chicago: The University of Chicago Press, 1998), xii.

5. Ibid., 29-91. 
part, a proliferation of double-entry bookkeeping as a practice. ${ }^{6}$ However, the mere presence of a polemics around the best method of bookkeeping signifies a profound shift from the previous era: bookkeeping was becoming an instrumental tool, rather than a constitutive record. Before the development of the negotiable instrument, bookkeeping was intimately tied up with notarial records, and took a similar form. As a record of debt and credit, the account book functioned as the record of a witness. But as the many arguments in favor of double-entry bookkeeping make clear, by the time double-entry was being talked about that function was largely lost. Clearly the function of bookkeeping in systems of proof did not vanish, but the way in which it functioned was altered in the period in which double-entry was introduced. Bookkeeping no longer witnesses an event, it references an event. Or more precisely, the functions of witness and reference are conflated when bookkeeping is used in contexts of proof.

To me, this is clearly an effect of changes which had already taken place elsewhere. Though bookkeeping was an important site for proof in the period before negotiability, afterwards the proof function of bookkeeping took on a decidedly secondary value. This was only possible because other contexts and methods of proof had already arisen to replace it. Chief among these was the negotiable instrument. What we see in double-entry bookkeeping, then, is the remainder of a system of proof which has ceased to function as such. Because of this, double-entry bookkeeping is a relatively poor site to study the practice of the promise, as the struggle to make decisions about promises had 6. Yamey, "Scientific Bookkeeping and the Rise of Capitalism," 105. 
moved elsewhere by the time this system of accounting arose. By the same measure, it is a relatively poor site to look for the origins of the modern fact-and I should again emphasize that Poovey does not do this. However, for one reason or another, perhaps because it polemically tries to distance itself from the practices of the previous period, double-entry bookkeeping does provide a particularly clear example of the modern fact and the modern mode of signification.

\subsection{Before the Variable}

Prior to the invention of the negotiable instrument in the sixteenth century, mathematical writing was specific. Abstraction was thought of as the motion from a thing to a class, a signified, ontologically distinct from its individual members, distinct from the referents that class might take on in ordinary speech. That is, though numbers and numberness might be talked about generally, when one wanted to refer to $a$ number, this had to happen either through an example — a specific number used with the understanding that one could repeat the method with other numbers-or through referring instead to what that number was. The idea of creating a class of numbers from the behavior of the equation itself—which was precisely what Descartes accomplished in his Geometry—was unknown. In mathematical writing, as in other writing of the time, it was imperative that one wrote according to the being of what was represented.

Looking at the way powers were named, we can gain some insight into the way mathematical signification was conceived prior to the sixteenth century. In modern 
Table 3.1: Pacioli's Notation for an Unknown and its Powers

\begin{tabular}{llll}
\hline 0 & $n^{o}$ & numero & number \\
1 & $c o$. & cosa & thing \\
2 & $c e$. & censo & square \\
3 & cu. & cubo & cube \\
$4(2 \times 2)$ & ce.ce. & censo di censo & square of square \\
5 & $p^{o} . r^{o}$. & primo relato & first inexpressible \\
$6(2 \times 3)$ & ce.cu. & censo di cubo & square of cube \\
7 & $2^{o} . r^{o}$. & secundo relato & second inexpressible \\
$8(2 \times 2 \times 2)$ & ce.ce.ce. & censo di censo di censo & square of square of square \\
$\ldots$ & & & \\
\hline
\end{tabular}

algebra, powers use an index notation; they are named by the order in which they are obtained from the process of repeated multiplication. But during the medieval period, powers referred to the geometrical entities which they expressed. In Luca Pacioli's 1494 Summa de Arithmetica (incidentally, the same book which first described double-entry bookkeeping), we see a typical notation for an unknown and its powers (Table 3.1). ${ }^{7}$ Everything is referred to by what it is, "cu." or "cubo" for a cube, "ce." or "censo" for a square. When powers beyond the cube are to be represented, we see a multiplicative scheme, ce.ce. or square of square, си.си. or cube of cube, etc., signifying what was the nearest geometrical analogue.

What is most striking about this notation is that the relation between the names for powers and the numbers we now use was not unknown at the time. For example, when multiplying powers, e.g. $\mathrm{cu}$. by ce.ce., the process was to look these up in a table, find the values 3 and 4 , add them together to get 7 , and then write this down as " $2^{\circ} . r^{o}$." There

7. I.G. Bashmakova and G.S. Smirnova, The Beginnings and Evolution of Algebra, trans. Abe Shenitzer (Washington, D.C.: The Mathematical Association of America, 2000), 62-63. 
were even brief moments where a more modern notation was actually used. For example, Nicholas of Oresme in the fourteenth century created a modern index notation for powers, and even recognized fractional powers. ${ }^{8}$ But all of this remained counterintuitive to an attitude that rigorously distinguished between what numbers are and what they $d o$.

\subsection{The Formation of the Variable}

With negotiability, meaning and function become synonymous. The negotiable variable, to bearer, means what it does. At the time of writing, to bearer cannot be said to refer to any actual object, but it fundamentally changes the potential behavior of the document. The negotiable variable then takes on meaning according to this changed behavior. Sanctified by an assured practical future, the dangling referent takes on the character of reference, though it signifies nothing but its own behavior.

This is exactly the type of signification and abstraction in which modern algebraic language participates. As Jacob Klein puts it, modern mathematics "determines its objects by reflecting on the way in which these objects become accessible through a general method." $"$ That is, the symbols of algebra mean according to how they function on the page.

As Klein points out, in what he terms the "ancient" (ancient Greek) and the

\footnotetext{
8. Florian Cajori, A History of Mathematical Notations (La Salle, IL: The Open Court Publishing Company, 1928), 91-93

9. Jacob Klein, Greek Mathematical Thought and the Origin of Algebra, trans. Eva Brann (Cambridge, MA: The M.I.T. Press, 1968).
} 
Signification: The Formation of the Variable 46 "modern" (modern European) period—-though this distinction could apply equally well to the practices of medieval and modern Europe - the differences in mathematical notation between the two periods correspond to different ideas about what constituted a number. To the "ancients," numbers were a definite countable thing. They were what we call the positive integers (or sometimes even only the positive integers from two forward, as the number one was seen as a more fundamental monadic quantity in terms of which numbers are understood).${ }^{10}$ A magnitude to the ancients—-which we would speak of as taking on any "value"-could only be expressed as a whole number or as a ratio of whole numbers. Otherwise—when it was an irrational (ádoyos) magnitude—it could not be expressed numerically, only geometrically. The differences in the ancient Greek understanding of number and of measure are part of what kept geometry and arithmetic separate until Descartes. In contrast, the modern understanding of number is essentially symbolic. ${ }^{11}$ The idea of irrational and imaginary numbers existing on a continuum with whole and rational numbers without serious distinction indicates our fundamentally transformed concept of number, where a number can be something uncountable and not representable in terms of any countable numbers, or can even be something indefinite yet nevertheless symbolically representable by a variable.

Viète, writing in the late sixteenth century, first substitutes variables for the unknowns as well as the knowns (which were previously universally represented by 10. Ibid., 36-60. 11. Ibid., 117-125. 
specific, exemplary numbers). This, for Viète, creates "species," both species of equations-equations with a certain character, based on their behavior—and species of numbers that would satisfy those equations. Viète, however, wrote in the midst of the transition between the medieval and modern mode of representation. Thus he insists on classifying all of these variables according to their order. For example "A plano" would denote a variable "A" that represented an area, and not a length or a volume. ${ }^{12}$ There were limitations on how various classes of number could mix, and generally it was clear that Viète still practiced algebra as something whose behavior had to be carefully conceived and monitored, that is, not—as we now conceive of algebraic practice—as a set of textual manipulations. In his insistence on a classification scheme for numbers, it is clear that Viète conceives of his species as defined by both their referent and their meaning, both their eventual possible numeric content attained in the course of calculation and their place in an a priori classification scheme.

In 1637, Descartes instituted modern algebra, using a notation that for the first time was nearly identical to the current notation (the only exception is that Descartes used the symbol " $\propto$ "—-derived from the $a$ of aqualis—instead of “=”). By carefully relating equations of any order to certain curves that could be drawn on a two-dimensional surface (parabolas, for example), Descartes made a somewhat rhetorical claim that all of the orders (plane, solid, line) were equivalent from the point of view of algebraic analysis, in

12. François Viète, Introduction to the Analytic Art, trans. J. Winfree Smith, in Jacob Klein, Greek Mathematical Thought and the Origin of Algebra, trans. Eva Brann (Cambridge, MA: The MIT Press, 1968), 324-326. 
opposition to the work of Viète and most other contemporary algebraists. ${ }^{13}$ With that accomplished, the equation was given a certain independence of what it represented. The double system of representation which was important to Viète and his successors was set aside, and the variables were now defined solely by their reference, by their behavior in an equation.

In the Geometry, Descartes writes:

$[\ldots]$ it should be remarked that this method of expressing the value of the roots by means of the relations which they bear to the sides of certain cubes whose contents only are known is in no respect clearer or simpler than the method of expressing them by means of the relations which they bear to the chords of certain arcs (or portions of circles), when arcs three times as long are known. ${ }^{14}$

In the same sentence as Descartes rejects the insistence on distinguishing between cubic numbers and numbers representing lengths, he rejects the mode of thought and representation which made that distinction necessary. For Descartes, the geometric objects—cubes or arcs—are merely "expressing the value" of the numbers. Here the entire mode of representation is reversed. The equation, which should be the representation, is the primary place in which the numbers are given value, whereas the objects of geometry, rather than representing the world, are spoken of as representing the equation, the abstraction. What we are seeing here is the espousal of a mode of thought that is not

13. René Descartes, The Geometry of René Descartes, trans. David Eugene Smith and Marcia L. Latham (n.p.: Dover Publications, 1954).

14. Ibid., 215. "[...] il eft a remarquer que cete façon d'exprimer la valeur des racines par le rapport qu'elles ont aux coftés de certains cubes dont il n'y aquele contenu qu' on connoiffe, n'eft en rien plus intelligible, ny plus fimple, que de les exprimer par le rapport qu'elles ont aux fubtenduës de certains arcs, ou portions de cercles, dont le triple eft donné." 
limited to algebraic notation, but actually changes and reverses the entire mode of signification. From the behavior of the symbol, we get its meaning; but the objects of the world, and our abstractions and thoughts concerning these objects, are themselves reduced to signs for behavior.

\subsection{Mode of Signification}

The modern mode of signification is characterized by a disjunction between the signified and the referent. Whereas prior to the sixteenth century each sign had to accord with its object, in modern writing the object becomes separated from the sign in a way that is both less and more ambiguous. What happens in the negotiable instrument is that "the bearer" ceases to mean the type of person who bears the letter-a messenger or lawyer, for example. In most legal situations, "bearer" has a meaning which is defined—as the variable by the equation - by those to whom it refers in the general use of the document. Thus the sign as a whole becomes a mere signifier for the referent. The process of signification here is consciously reversed: the referent determines the meaning of the sign. Who is the "bearer"? This question can be answered deictically any time it is asked. And yet it would be impossible to say what the phrase meant before the events that are to give it meaning take place. This absolute correspondence between the referent and the meaning_absolute because it is definitional, the sign is defined by its referents-leads to a general confusion of referent and meaning and a feeling of unambiguity in the language, despite the fact that in a certain sense the ambiguity has increased. 
In contrast to this, the mode of signification throughout the medieval period, as well as during Greek antiquity, is characterized by an acute consciousness of the gap between the signified and the referent. This consciousness is the source of the fundamental conflict between the Platonic and Aristotelian conceptions of the $\iota \delta \epsilon ́ \alpha$. For Plato, individual things themselves, far from being the ultimate meaning of language, function as signifiers for the signified, the object of knowledge, the so-called Platonic forms. Plato's famous tirade against poets in the tenth book of the Republic is possible because of this: poets, rather than trying to come to the source of language, merely use it to describe, to refer to things, and those things themselves then indicate and remind us of the forms, the signified. ${ }^{15}$ Language that functions merely to refer is thus twice removed. For Aristotle, on the other hand, the forms come to us through observation; physical objects give us the forms themselves. The relative position of the objects in Aristotle's ontology have shifted, but the terms have remained the same. For Aristotle, as for Plato, the individual referent is not, properly speaking, an object of knowledge: “[...] it is not the stone which is present in the soul but its form [ $\left[\epsilon^{\prime} \delta o s\right] . " 16$ The object of knowledge is still meaning, never referent.

These problems are diluted by Viète when he proposes a species of number. In formulating this species, Viète erodes the distinction between class and individual. If one is to view the variable as a species, this could only be as an aggregate of its individual elements (numbers), and not as a category created by a quality that runs through these

15. Plato, The Republic of Plato, trans. Allan Bloom (n.p.: Basic Books, 1991), 277-291.

16. Aristotle, On the Soul, trans. J.A. Smith, in The Basic Works of Aristotle, ed. Richard McKeon (New York: The Modern Library, 2001), bk. 3, ch. 7, p. 595. 
numbers. Or rather, Viète intentionally conflates these two things in order to try to create the idea of a quality numbers possess by virtue of their manipulation in an equation. By 1637, Descartes no longer needs to explicitly argue for a species of number. The possibility of an aggregate taking the place of a class is already established.

During the sixteenth and seventeenth centuries, a general practice of signification evolved that conflates signified and referent, class and aggregate. The gap between the signified and the referent loses its importance, the sign becomes a signifier, and the signified is overlooked. Instead of categories and $\iota \delta^{\prime} \alpha_{\alpha}$, we are left with the modern fact and its use within theories built upon the concept of the variable.

\subsection{Epistemic Justice}

If, as I maintain, there are deep connections between something as foundational and abstract as algebra and something as materially rooted as finance, then we must acknowledge two things in our own practices.

First, the thoughts that are generated by social formations-even, to contradict Althusser, our most "scientific" thoughts—are dependent on and reinforced by our economic practices. What this means is that we cannot resist these thoughts only through intellectual means. For example, the ideological problems caused by the idea of a brute, unquestionable fact have been the subject of many texts produced within the humanities. But no matter how much we explain that a brute fact is an ideological structure that stops critique, when we wish to make a large payment, we write a check, and every part of its 
language and our participation make clear the actuality of facts. What this means is that even if we intend a purely ideological transformation, we are forced to consider social transformations as well. We must acknowledge that we may not be able to bring about a change of consciousness without a corresponding socioeconomic change.

Second, the societies we create put bounds on our intellectual lives as well as our material lives. If our economic choices generate intellectual results, then equity cannot be the sole consideration of social justice. Social justice must take into account the truth-effects that a given practice might have. It seems possible that certain more materially equitable social configurations may nevertheless imply a theory of truth that is obscurantist, authoritarian, or some other less desirable trait. The process of enumerating these traits has not even begun, as the assumption has largely been that deception is the sole problem here (or chauvinism in the case of relativists). It seems to me that the question of truth-effects has been almost entirely left out of the discourse around social justice, and consequently there are countless questions that have not yet even been asked, no less answered. We are only just beginning to approach this subject in postcolonial studies, where we must consider who has the epistemic right to judge what is just or unjust, and what one must do to obtain this right. Amidst the cries for social justice, there ought to be a cry for some sort of epistemic justice, a recognition that despite the social relativity of our epistemic position—or possibly because of this social relativity-certain socioepistemic positions are more desirable than others, and we must fight for socioeconomic systems from which those positions can become tenable. 


\section{References}

Agamben, Giorgio. State of Exception. Translated by Kevin Attell. Chicago: University of Chicago Press, 2009.

Ali, Syed. Dubai: Gilded Cage. New Haven: Yale University Press, 2010.

Aristotle. On the Soul. Translated by J.A. Smith. In The Basic Works of Aristotle, edited by Richard McKeon, 533-603. New York: The Modern Library, 2001.

Austin, J.L. How to Do Things with Words. Cambridge, MA: Harvard University Press, 1975.

Bashmakova, I.G., and G.S. Smirnova. The Beginnings and Evolution of Algebra.

Translated by Abe Shenitzer. Washington, D.C.: The Mathematical Association of America, 2000.

Bharadwaj, Vinita. “A Kind Ear for Unsung Heroes.” The National, 27 December 2008. Accessed 21 February 2011. http://www. thenational.ae/lifestyle/ personal-finance/a-kind-ear-for-unsung-heroes. . "Sending It All Back Home.” The National, 12 September 2009. Reprinted by Pravasi Bandhu. Accessed 21 February 2011. http://pravasibandhu. blogspot.com/2009/09/sending-it-all-back-home.html.

Bowman, William Dodgson. The Story of the Bank of England, from Its Foundation in 1694 until the Present Day. London: H. Jenkins, Limited, 1937.

Boyer-Xambeu, Marie-Thérèse, Ghislain Deleplace, and Lucien Gillard. Private Money and Public Currencies: The 16th Century Challenge. Armonk, NY: M.E. Sharpe, 1994. 
Braudel, Fernand. Civilization and Capitalism, 15th-18th Century: The Wheels of Commerce. New York: Harper and Row Publishers, 1982.

Cajori, Florian. A History of Mathematical Notations. La Salle, IL: The Open Court Publishing Company, 1928.

De Roover, Raymond. Money, Banking, and Credit in Mediaeval Bruges: Italian Merchant-Bankers, Lombards and Money-Changers-A Study in the Origins of Banking. Cambridge, MA: Mediaeval Academy of America, 1948.

—. L'Évolution de la Lettre de Change, XIVe-XVIIIe siècles. Paris: Librarie Armand Colin, 1953.

—. "What is Dry Exchange? A Contribution to the Study of Mercantilism." In Business, Banking, and Economic Thought in Late Medieval and Early Modern Europe: Selected Studies of Raymond de Roover, edited by Julius Karshner, 183-199. Chicago: The University of Chicago Press, 1974.

Denzel, Markus A. “The European Bill of Exchange.” In Cashless Payments and Transactions from the Antiquity to 1914, edited by Sushil Chaudhuri and Markus A. Denzel, 153-194. Stuttgart: Franz Steiner Verlag, 2008.

Descartes, René. The Geometry of René Descartes. Translated by David Eugene Smith and Marcia L. Latham. N.p.: Dover Publications, 1954.

Dharmarajan, Subramani. "Unbearable Demands: Broken Promise.” gulfnews.com, 23 October 2008. Accessed 30 October 2010. http: / / gulfnews.com/news / gulf/uae/general/unbearable-demands-broken-promise-1. 459654.

“Dubai Faces Gradual Exodus of Expatriate Workers.” Tehran Times, 7 January 2010. 
Accessed 30 October 2010.

http: //www.tehrantimes.com/index_View.asp?code=211675.

Foucault, Michel. Security, Territory, Population: Lectures at the College de France, 1977-1978. Edited by Michel Senellart. Translated by Graham Burchell. New York: Picador, 2007.

Galal, Ola. "Dubai's Expatriate Workers Feel Pinch of Debt Crisis." Monsters and Critics, 12 December 2009. Accessed 30 October 2010.

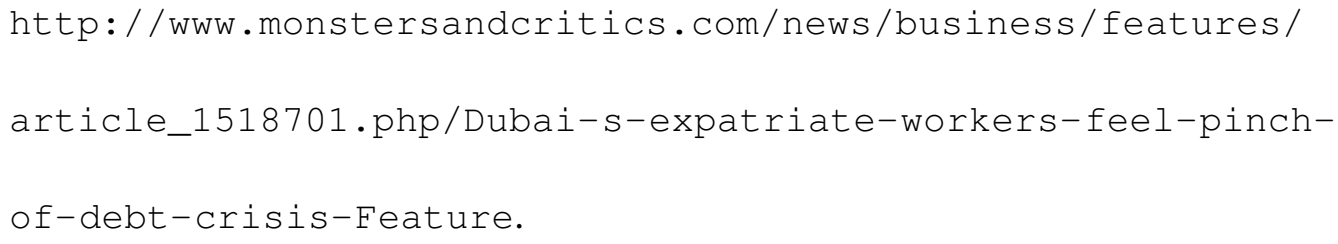

Hari, Johann. "The Dark Side of Dubai." The Independent, 7 April 2009. Accessed 30 October 2010.

http://www. independent. co.uk/opinion/commentators/johannhari/the-dark-side-of-dubai-1664368.html.

Klein, Jacob. Greek Mathematical Thought and the Origin of Algebra. Translated by Eva Brann. Cambridge, MA: The M.I.T. Press, 1968.

Lawrence, Jeremy. "Debt in Dubai.” Time Out Dubai, 9 February 2009. Accessed 30 October 2010. http://www.timeoutdubai.com/knowledge/features / 6433-debt-in-dubai.

Marx, Karl. "Introduction to a Contribution to the Critique of Political Economy." Marxists Internet Archive. Last modified 2009. Accessed 7 June 2010. http://www.marxists.org/archive/marx/works/1859/critique- 
pol-economy/appxl.htm.

Menon, Sunita. "Desperate Laborers Seek Death on Roads." gulfnews.com, 29 March 2006. Accessed 30 October 2010.

http://gulfnews.com/news/gulf/uae/traffic-transport/ desperate-labourers-seek-death-on-roads-1.230710.

Munro, John. "The International Law Merchant and the Evolution of Negotiable Credit in Late-Medieval England and the Low Countries." In Textiles, Towns and Trade: Essays in the Economic History of Late-Medieval England and the Low Countries, 49-80. Aldershot, Hampshire, UK: Variorum, 1994.

Nietzsche, Friedrich. On the Genealogy of Morality. Translated by Carol Diethe. Cambridge: Cambridge University Press, 2007.

“Personal Letter from Simon Ford, bluebanana.com.” arabianbusiness.com, 24 June 2009. Accessed 30 October 2010. http://www . arabianbusiness.com/simonford-s-emotional-letter-in-full-16770.html.

Plato. The Republic of Plato. Translated by Allan Bloom. N.p.: Basic Books, 1991.

Poovey, Mary. A History of the Modern Fact: Problems of Knowledge in the Sciences of Wealth and Society. Chicago: The University of Chicago Press, 1998.

Postan, M.M. "Private Financial Instruments in Medieval England." In Medieval Trade and Finance, 28-64. Cambridge: Cambridge University Press, 1973.

Pravasi Bandhu Welfare Trust. "Our Mission.” Paravasi Bandhu Welfare Trust. Accessed 21 February 2011. http://www.pravasibandhu.com/about/.

Rhode, Steve. "Bouncing a Check Can Put You Behind Bars for Years in Dubai." How to 
Get out of Debt, 14 September 2009. Accessed 30 October 2010.

http://getoutofdebt.org/7891/bouncing-a-check-can-put-youbehind-bars-for-years-in-dubai.

Rogers, James Steven. The Early History of the Law of Bills and Notes: A Study of the Origins of Anglo-American Commercial Law. Cambridge: Cambridge University Press, 1995.

Simpson, A.W.B. A History of the Common Law of Contract: The Rise of the Action of Assumpsit. Oxford: Clarendon Press, 1975.

Surk, Barbara. "Jail Time is Cost for Not Paying Debts in Dubai." The Seattle Times, 12 June 2007. Accessed 30 October 2010. http: / / seatt letimes . nwsource. com/html/nationworld/2003744014_debtors12.html.

“The Real Debt Prison in United Arab Emirates UAE.” DebtPrison.net, 3 February 2009. Accessed 21 February 2011. http: // debtprison. net/wordpress/297/ the-real-debt-prison-in-united-arab-emirates-uae/.

Van der Wee, Herman. "Antwerp and the New Financial Methods of the 16th and 17th Centuries." In The Low Countries in the Early Modern World, 145-166. Translated by Lizabeth Fackelman. Aldershot, Hampshire, UK: Variorum, 1993.

Verma, Sonia. “Driven Down by Debt, Dubai Expats Give New Meaning to Long-Stay Car Park.” The Times, 5 February 2009. Accessed 30 October 2010. http://business.timesonline.co.uk/tol/business/markets/the_ gulf/article5663618.ece.

Viète, François. Introduction to the Analytic Art. Translated by J. Winfree Smith. In Jacob 
Klein, Greek Mathematical Thought and the Origin of Algebra, translated by Eva Brann, 315-353. Cambridge, MA: The MIT Press, 1968.

Weber, Max. Economy and Society: An Outline of Interpretive Sociology. Edited by

Guenther Roth and Claus Wittich. Berkeley: University of California Press, 1978.

Yamey, B.S. "Scientific Bookkeeping and the Rise of Capitalism." The Economic History

Review 1, nos. 2 and 3 (1949): 99-113. 